\title{
Eastern Cranberry Bee Melitta americana Smith (Insecta: Hymenoptera: Melittidae: Melitta) ${ }^{1}$
}

\author{
Lidia Komondy and Cameron Jack ${ }^{2}$
}

The Featured Creatures collection provides in-depth profiles of insects, nematodes, arachnids and other organisms relevant to Florida. These profiles are intended for the use of interested laypersons with some knowledge of biology as well as academic audiences.

\section{Introduction}

Melitta americana Smith (1853) is a species of solitary bee in the family Melittidae (Figure 1). Melittid bees are solitary, exhibit no overlap in generations and each laying female cares only for her nest. Melitta americana bees are typically found in temperate regions where they create their nests in loose soils and sands. Adults exhibit an oligolectic feeding preference meaning they have a narrow preference for flowers of only a few genera or species (Michez 2008). Melitta is the most diverse bee genus, with nearly 50 species, in the Melittidae bee family, although only five species are found in the United States (Wilson et al. 2016). The oldest known fossil of any bee is thought to be about 100 million years old and is a specimen from this family (Dewulf et al. 2014).

\section{Distribution}

Melitta americana was first described by John B. Smith in 1853. It has been reported in and is native to the eastern United States and Canada, inhabiting the Boreal Shield Ecozone (Figure 2). Melitta americana range from Louisiana to the east coast of the United States and from Florida into Canada (Payette 2013).

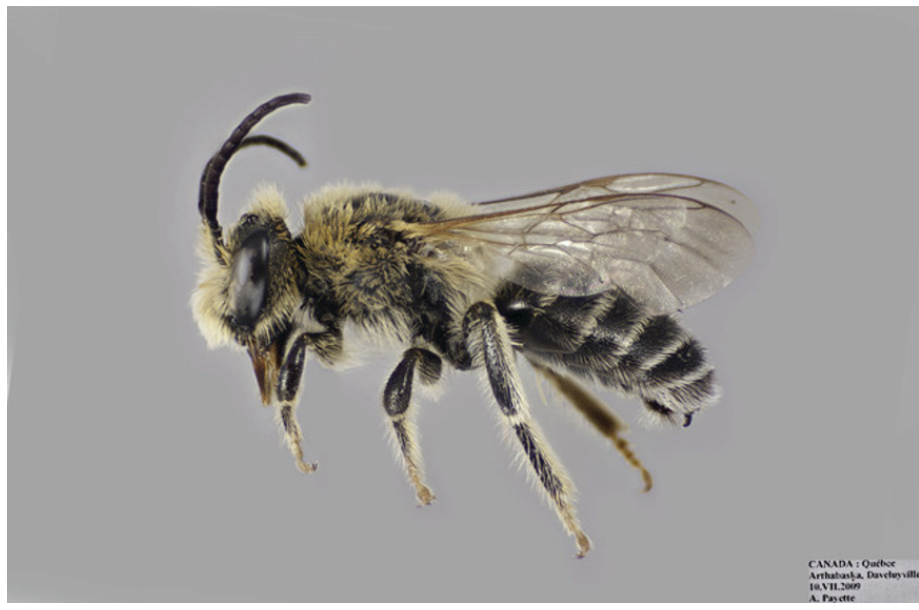

Figure 1. An adult male Melitta americana Smith. Credits: Lawrence Packard 2014, York University



Figure 2. Identification localities of Melitta americana Smith, collected from the eastern United States and Canada.

Credits: DiscoverLife.org in partnership with the American Museum of Natural History Bee Biology and Systematics Laboratory and the Cornell University Insect Collection

1. This document is EENY-772, one of a series of the Entomology and Nematology Department, UF/IFAS Extension. Original publication date June 2021. Visit the EDIS website at https://edis.ifas.ufl.edu for the currently supported version of this publication. This document is also available on the Featured Creatures website at http://entnemdept.ufl.edu/creatures/.

2. Lidia Komondy; and Cameron Jack; Entomology and Nematology Department, UF/IFAS Extension, Gainesville, FL 32611.

The Institute of Food and Agricultural Sciences (IFAS) is an Equal Opportunity Institution authorized to provide research, educational information and other services

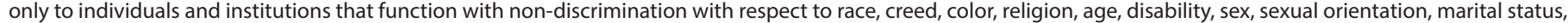


U.S. Department of Agriculture, UF/IFAS Extension Service, University of Florida, IFAS, Florida A \& M University Cooperative Extension Program, and Boards of County Commissioners Cooperating. Nick T. Place, dean for UF/IFAS Extension. 


\section{Description}

Adult Melitta americana resemble many other types of solitary bees. The head, thorax, abdomen, and legs are black and lightly covered in hair ranging from yellow and orange to light brown. The wings are transparent with a light brown hue and dark brown venation (Figure 3).



Figure 3. Dorsal view of Melitta americana Smith.

Credits: Brooke Alexander, courtesy of United States Geological Survey, Native Bee Inventory and Monitoring Laboratory

The antennae of melittid species are geniculate or bent abruptly, with a barrel-like basal segment (scape) that forms an elbow shape when met with the pedicel or second antennal segment (Figure 4). In nearly all melittid species, females have 10 flagomeres (antennal segments) and males have 11. This morphological feature gives taxonomists a relatively quick way to discern males from females. Additional melittid characteristics include the occurrence of a corbicula or pollen basket on the hind legs of females and clusters of hairs on the leg segments (Wilson et al. 2016). In Figure 5, a Melitta americana female is at rest with extended wings to the posterior, about $9 \mathrm{~mm}$ long from the vertex of the head to the tip of the wing.

\section{Life cycle and Biology}

Adult Melitta americana begin emerging in early spring depending on the region and climate. After mating, the female looks for suitable nest sites in loose soils. She then chooses a spot to begin excavating a nest. Like many species of solitary bee, females spend most mornings and afternoons foraging and evenings in nest construction. Like other melittid bees, female Melitta americana line the walls of each cell with a glandular secretion to increase the longevity and hardiness of the cell before egg laying
(Michez et al. 2008). Females then provision their young with pollen through the larval stages until emergence in the spring (Norden 1984). Beyond these details, little else is known about the nesting habits of Melitta americana. However, it can be inferred that some of their nesting and life reproductive behaviors based on studies limited to a few European species in the genus Melitta (Wilson et al. 2016).

Adult Melitta americana are known to forage largely on blueberry and cranberry (Vaccinium spp.), collecting both pollen and nectar (Payette 2013). This bee will forage in light rain and moderate temperatures. Researchers have found that Melitta americana are often the most frequent pollinators of these plants in North America (Payette 2013). Melitta species are efficient pollinators because they 'buzz pollinate, a technique used by bees to release pollen which is more firmly attached to the anthers of many floral species (Wilson et al. 2016).



Figure 4. Antennae of Melitta americana Smith, showing a barrel-like basal segment (scape) that forms an elbow shape when met with the pedicel antennal segment.

Credits: Brooke Alexander, courtesy of United States Geological Survey, Native Bee Inventory and Monitoring Laboratory

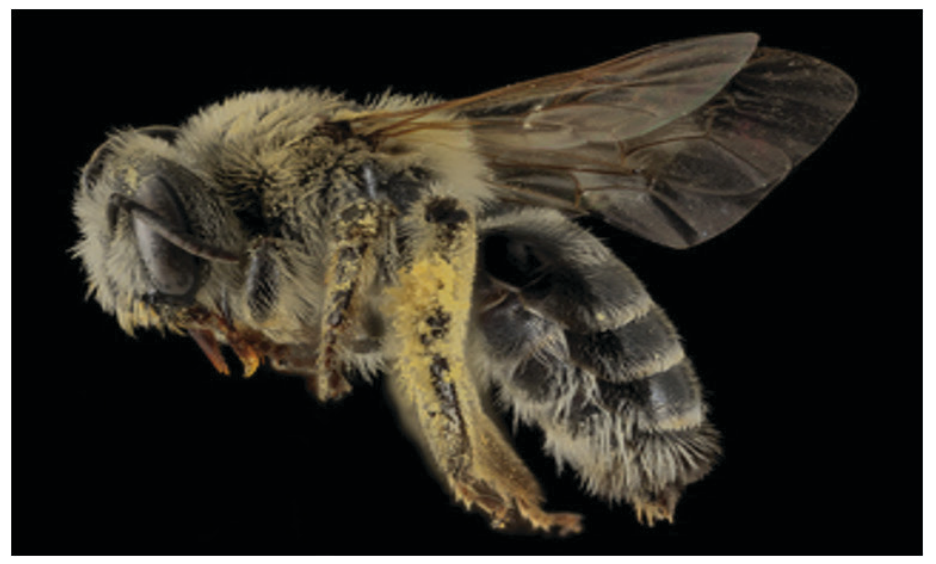

Figure 5. Lateral view of Melitta americana Smith.

Credits: Brooke Alexander, courtesy of United States Geological Survey, Native Bee Inventory and Monitoring Laboratory 


\section{Economic Impact}

Melitta americana is a very important insect in the agricultural industry due to its impressive pollination rate and corresponding increased fruiting of cranberries (Payette 2013). While Melitta americana are floral specialists of blueberry and cranberry flowers (Payette 2013), these bees have also been found foraging on deerberry, Allegheny blackberry, red raspberry, and yellow loosestrife (Cane 1985).

Melitta americana have unique and efficient pollination qualities that highlight them as ideal candidates for future study and the focus of conservation efforts. When properly managed, yards and gardens can provide critical nesting sites for Melitta species as their habitats begin to vanish. Homeowners and growers can promote the conservation and fitness of these bees by adhering to the labels of pesticide products that can be harmful to pollinators, as well as providing an abundance of diverse floral hosts. In addition, providing healthy, balanced soils and a water source can benefit many species of bees including Melitta americana.

\section{Selected References}

Cane JH, Eickwort GC, Wesley FR, Spielholz J. 1985.

Pollination ecology of Vaccinium stamineum (Ericaceae: Vaccinioideae). American Journal of Botany 72: 135-142.

Dewulf A, DeMeulemeester T, Dehon M, Engel MS, Michez D. 2014. A new interpretation of the bee fossil Melitta willardi Cockerell (Hymenoptera: Melittidae) based on geometric morphometrics of the wing. Zookeys 389: 35-48.

Michez D, Patiny S, Rasmont P, Timmermann K, Vereecken NJ. 2008. Phylogeny and host-plant evolution in Melittidae sp. (Hymenoptera: Apoidea). Apidologie 39: 146-162.

Norden BB. 1984. Nesting biology of Anthophora abrupta (Hymenoptera: Anthophoridae). Journal of the Kansas Entomological Society 57: 243-262.

Payette A. 2013. First record of the bee Melitta americana (Smith) (Hymenoptera: Melittidae) for Quebec and

Canada. The Canadian Field-Naturalist 127(1): 60-63.

Wilson JS, Messinger-Carril O. The bees in your backyard: a guide to North America's bees. 2016. Princeton University Press, Princeton, NJ 288 pp. 